\title{
Examining Wax Chemistry through Encaustics
}

\author{
Susan Wright, David Soriano, Richard Shires, and Sarah E. Ruffell
}

\author{
University of Pittsburgh at Bradford, Department of Biology, 300 Campus Dr, Bradford PA \\ 16701 USA \\ (sjw80@pitt.edu; soriano@pitt.edu; rls70@pitt.edu; ruffell@pitt.edu)
}

\begin{abstract}
Chemically, waxes are composed of mixtures of esters in that the acyl and alkyl groups are non-branched and usually have a dozen or more carbon chains. Waxes have been used since 100AD to create encaustic paintings, also known as hot wax paintings. During this exercise, properties of waxes were explored and through this process, the students were able to create their own, unique art piece. This lab is well suited for an introductory chemistry course; thus, students would require a high school understanding of chemistry. Students coated a glass jar in gesso and paint the container with colored hot waxes. This activity takes 1 hour and can be completed individually. The exercise allows students to learn the chemistry of waxes, while simultaneously handling and designing a unique piece of art which they can take home. In this workshop, there was a short presentation regarding the overall exercise and then participants had the opportunity to complete part of the lab exercise.
\end{abstract}

Keywords: waxes, encaustics

Link to Original Poster File: https://doi.org/10.37590/able.v41.poster88

\section{Mission, Review Process \& Disclaimer}

The Association for Biology Laboratory Education (ABLE) was founded in 1979 to promote information exchange among university and college educators actively concerned with teaching biology in a laboratory setting. The focus of ABLE is to improve the undergraduate biology laboratory experience by promoting the development and dissemination of interesting, innovative, and reliable laboratory exercises. For more information about ABLE, please visit http:// www.ableweb.org/.

Advances in Biology Laboratory Education is the peer-reviewed publication of the conference of the Association for Biology Laboratory Education. Published articles and extended abstracts are evaluated and selected by a committee prior to presentation at the conference, peer-reviewed by participants at the conference, and edited by members of the ABLE Editorial Board. Published abstracts are evaluated and selected by a committee prior to presentation at the conference.

\section{Citing This Article}

Wright S. 2020. Examining wax chemistry through encaustics. Article $88 \mathrm{In}$ : McMahon K, editor. Advances in biology laboratory education. Volume 41. Publication of the 41st Conference of the Association for Biology Laboratory Education (ABLE). https://doi.org/10.37590/able.v41.abs88

Compilation (C) 2020 by the Association for Biology Laboratory Education, ISBN 1-890444-17-0. All rights reserved. No part of this publication may be reproduced, stored in a retrieval system, or transmitted, in any form or by any means, electronic, mechanical, photocopying, recording, or otherwise, without the prior written permission of the copyright owner.

ABLE strongly encourages individuals to use the exercises in this volume in their teaching program. If this exercise is used solely at one's own institution with no intent for profit, it is excluded from the preceding copyright restriction, unless otherwise noted on the copyright notice of the individual chapter in this volume. Proper credit to this publication must be included in your laboratory outline for each use; a sample citation is given above. 